\title{
Kajian Aplikasi Pupuk Organik Pada Tumpang Sari Tanaman Kelor-Selada Di Lahan Kering
}

\author{
Study of Organic Fertilizer Application in Moringa-Lettuce \\ Intercropping System in Dry land
}

\author{
I Gusti Made Arya Parwata*, I Komang Damar Jaya, Bambang Budi Santoso, Jayaputra \\ Kelompok Peneliti Pengembangan Pertanian Lahan Kering, \\ Fakultas Pertanian Universitas Mataram, INDONESIA \\ *corresponding author, email: arya.parwata@unram.ac.id
}

Manuscript received: 11-06-2019. Accepted: 20-06-2019

\begin{abstract}
ABSTRAK
Selada dan kelor merupakan tanaman sayuran yang akhir-akhir ini mendapat perhatian karena kebutuhan yang terus meningkat, dan pengembangannya diarahkan ke lahan kering karena potensi lahan kering di Indonesia masih sangat tinggi. Penggunaan lahan kering perlu diiringi dengan penerapan sistem tumpang sari sehingga iklim mikro tanaman menjadi lebih optimum. Disamping itu, dengan rendahnya tingkat kesuburan tanah dan tingginya penggunaan saprodi anorganik, maka aplikasi pupuk organik menjadi keharusan. Penelitian ini bertujuan untuk memperoleh jenis pupuk organik yang dapat memberikan hasil tinggi pada tanaman kelor dan selada yang ditanam secara tumpang sari di lahan kering. Hasil penelitian menunjukkan bahwa aplikasi pupuk organik pada tumpang sari kelor-selada meningkatkan pertumbuhan dan hasil tanaman kelor dan selada, serta meningkatkan produktivitas lahan. Nilai kesetaraan lahan tertinggi ditunjukkan oleh perlakuan aplikasi pupuk organik Organox, diikuti oleh Bio Extrim dan Biota Plus, serta terendah terdapat pada perlakuan tanpa pupuk organik.
\end{abstract}

Kata kunci: sayuran; organox; bio ekstrim; super biota plus; pertumbuhan, hasil

\begin{abstract}
Lettuce and Moringa are recently popular vegetable crops because their demand improves significantly, and their development lead to dry land because its potencial in Indonesia is still high. The use of dry land should be followed by applying inter cropping technique in order to make plant micro climate becomes more favourable. In addition, low soil fertility and intensive ussage of inorganic fertilizers makes the application of organic fertilizers imperative. The objective of the research is to investigate the type of organic fertilizer giving high yield of lettuce and moringa cultivated using inter cropping technique in dry land. The results showed that the organic fertilizers applied improved the plant growth and yield, and also improved the land equivalent ratio (LER). The highest LER was showed by apllication of Organox, followed by Bio Extrim and Biota Plus, and the lowest one showed by without organic fertilizer application.
\end{abstract}

Keyword: vegetable; organox; bio ekstrim; super biota plus; growth; yield. 


\section{PENDAHULUAN}

Sayuran merupakan salah satu pangan yang dibutuhkan karena kandungan vitamin, mineral dan gizi lainnya yang tinggi. Permintaan pasar akan sayuran dari hari ke hari terus meningkat sejalan dengan meningkatnya jumlah penduduk, perkembangan ilmu pengetahuan dan teknologi, serta kesadaran masyarakat akan arti penting, manfaat, fungsi dan gizi sayuran (Rini dan Sumarni, 2005).

Peningkatan permintaan terhadap sayuran harus diimbangi dengan peningkatan produktivitas sayuran. Beberapa jenis sayuran mempunyai potensi produksi yang tinggi sehingga layak untuk dikembangkan, antara lain selada. Tanaman sayuran selada daun memiliki potensi produksi 12 ton.ha ${ }^{-1}$, dan sejak tahun 1980an permintaannya di dalam negeri terus meningkat, terutama di pasar-pasar, swalayan, restauran-restauran dan hotel berbintang yang sering dikunjungi oleh wisatawan manca negara (Deptan, 2017).

Tanaman sayuran lainnya yang akhir-akhir ini mendapat perhatian besar adalah kelor. Kelor (Moringa oleifera Lam.) merupakan salah satu tanaman ajaib, tidak hanya sebagai sumber pangan, pengobatan, dan makanan ternak (Edward et al, 2014), tetapi juga dapat digunakan sebagai sumber energi alternatif bahan bakar (biodiesel) yang ramah lingkungan (da Silva, et al, 2010; Rashid et al, 2008). Tanaman ini menjadi pilihan yang layak karena dapat hidup di lahan kritis. Oleh karena itu, pengusahaan tanaman ini mampu menyediakan bahan bakar alternatif atau substitusi, dapat meningkatkan taraf hidup dan tambahan penghasilan masyarakat (khususnya petani), dapat menanggulangi kemiskinan dan penambahan devisa negara, dan memperbaiki lingkungan, serta sekaligus penyangga sumber pangan dan obat.

Pengembangan kedua jenis tanaman sayuran tersebut di lahan basah menjadi terkendala karena alih fungsi lahan, terutama di daerah perkotaan sangat pesat. Di sisi lain, potensi lahan kering yang tinggi dan belum digarap dengan maksimal. Lahan kering di Indonesia merupakan lahan yang potensial dilihat dari luasan yang ada. Berdasarkan data yang dibuat oleh Puslitbangtanah (Pusat Penelitian dan Pengembangan Tanah dan Agroklimat, 2002), potensi lahan kering di Indonesia sekitar 75,133,840 ha. Provinsi Nusa Tenggara Barat memiliki luas wilayah 20.153,15 km2, yang didominasi oleh lahan potensial yaitu 84,19\% yang berupa lahan kering (BPS, 2002). Potensi pertanian lahan kering di Kabupaten Lombok Utara sekitar 38.000 hektar dan baru 30\% dimanfaatkan untuk pengembangan tanaman pangan, seperti jagung dan ubi kayu (Agustina dan Semaun, 1995).

Upaya peningkatan hasil hasil tanaman sayuran dapat dilakukan dengan perbaikan teknologi budidaya. Salah satunya adalah perbaikan teknologi tumpangsari pada tanaman sayuran. Sistem tersebut pada dasarnya mengkombinasikan antara tanaman yang memiliki interaksi yang menguntungkan. Tumpangsari adalah suatu bentuk pola tanam dengan menanam lebih dari satu jenis tanaman pada lahan yang sama dalam waktu yang bersamaan. Tujuan dari penerapan pola tanam demikian adalah untuk meningkatkan produktifitas lahan dengan memanfatkan keragaman sifat pertumbuhan tanaman, seperti sistem perakaran dan tajuk, serta perbedaan respon tanaman terhadap faktor iklim, terutama cahaya dan suhu udara (Baldy dan Stigter, 1997 dalam Zulkarnain, 2005). Selain itu tercipta iklim mikro yang lebih baik ditinjau dari perkembangan hama, penyakit dan gulma, dibandingkan dengan tanaman monokultur, terutama sekali pada lahan sub optimal seperti lahan kering. 
Pupuk merupakan salah satu faktor yang sangat berperan penting dalam pertumbuhan dan hasil tanaman, baik dalam sistem tumpang sari maupun monokultur. Hasil tanaman yang tinggi dapat tercapai apabila faktor-faktor yang menunjang pertumbuhan tanaman dalam keadaan optimum. Pemberian hara yang optimal dapat dilakukan menggunakan pemupukan yang berimbang. Pemupukan berimbang untuk tercapainya produksi optimum dapat dilakukan dengan memperhatikan status hara dan kebutuhan tanaman akan hara tersebut.

Pemupukan dapat dilakukan dengan dua cara yaitu melalui tanah dan melalui daun. Pemupukan melalui tanah yaitu memberikan bahan-bahan atau unsur-unsur melalui tanah, sedangkan pemupukan melalui daun yaitu memberikan bahan-bahan atau unsur-unsur melalui daun dengan cara disemprotkan agar dapat langsung diserap agar mencukupi kebutuhan hara bagi pertumbuhan dan perkembangan tanaman. Pemberian pupuk daun diharapkan dapat membantu ketersediaan hara secara lebih cepat. Lingga et al. (2006) menambahkan bahwa penggunaan pupuk melalui daun akan memberikan keuntungan yang lebih besar karena penyerapan unsur hara berjalan lebih cepat dari pada pupuk diberikan melalui akar.

Pemberian pupuk pada tanaman menjadi sangat penting karena tanaman membutuhkan unsur hara yang cukup untuk pertumbuhan dan perkembangannya. Penggunaan pupuk anorganik atau pupuk sintetik yang berlebihan dapat mencemari lingkungan dan bersifat toksik baik terhadap tanaman ataupun konsumen yang mengkonsumsi produk tersebut. Untuk mengatasi permasalahan tersebut dapat menggunakan pupuk organik yang aman untuk lingkungan dan kesehatan konsumen. Beberapa pupuk organik yang dapat digunakan untuk meningkatkan hasil tanaman sayuran adalah pupuk cair organik Organox, Super Biota Plus dan Bio-Ekstrim. Informasi tentang penggunaannya pada tumpang sari tanaman kelor dan selada di lahan kering masih sangat terbatas.

\section{BAHAN DAN METODE}

Keseluruhan rangkaian percobaan telah dilaksanakan di lahan kering di Desa Gumantar, Kecamatan Kayangan, Kabupaten Lombok Utara, Nusa Tenggara Barat, yang dimulai dari bulan Mei hingga bulan November 2018.

Dalam percobaan ini dikaji tiga jenis pupuk organik, yaitu pupuk organik Organox, Bio Extrim, Super Biota Plus dan tanpa pupuk organik (control). Masing-masing perlakuan jenis pupuk organik dan tanpa pupuk organik (kontrol) dibuat dalam 3 ulangan. Disamping itu, juga dibuat petak tanaman untuk monokultur, baik untuk selada maupun kelor masing-masing 3 ulangan.

Benih kelor diperoleh dari Desa Salut, Kecamatan Kayangan Kabupaten Lombok Utara. Benih yang digunakan berasal dari buah yang telah kering, kemudian dikupas dan dikering anginkan selama 24 jam, dan siap untuk digunakan. Benih selada diperoleh dari salah satu toko saprodi pertanian di Sweta, Mataram.

Media pesemaian baik untuk selada maupun kelor yang digunakan berupa campuran antara tanah dan pupuk kandang dengan perbandingan $2: 1(\mathrm{v} / \mathrm{v})$ yang sebelumnya diayak terlebih dahulu. Media kemudian ditempatkan pada bak kecambah dan siap digunakan. Media pembibitan kelor menggunakan media yang sama yang ditempatkan dalam polibag yang 
berukuran 20 x $26 \mathrm{~cm}$. Media penyemaian dan pembibitan disiram dan kemudian ditiriskan. Media siap digunakan.

Benih selada disemaikan pada kotak semai yang telah disediakan dan diatur jaraknya sehingga tidak mengumpul pada satu tempat. Setelah itu ditutup dengan tanah yang tipis, kemudian dilakukan penyiraman. Untuk kelor, benih direndam terlebih dahulu selama semalam dan kemudian ditiriskan. Benih disemaikan dengan kedalaman $1 \mathrm{~cm}$, kemudian ditutup dengan media semai.

Pesemaian disiram setiap hari atau disesuaikan dengan kondisi media pesemaian agar tidak terjadi kekeringan dengan menggunakan sprayer halus. Pengendalian hama, penyakit dan gulma disesuailan dengan kondisi pesemaian. Untuk selada, semai sudah siap ditanam/dipindah ke lapangan setelah berumur 4 minggu. Untuk kelor, semai dipindahkan ke polibag setelah berumur antara 7 - 10 hari (fase pancing). Pindah tanam dilakukan secara hatihati dengan bantuan bilah bambu agar perakaran tidak rusak. Pemeliharaan bibit di polibag dilakukan berupa penyiraman, pemupukan, pengendalian hama, penyakit dan gulma yang disesuaikan dengan keadaan pembibitan hingga berumur 2 bulan, dan bibit siap untuk dipindah tanam ke lapangan.

Lahan yang digunakan dalam percobaan ini dibersihkan, dibajak dan diratakan. Petakpetak percobaan dibuat dengan ukuran $200 \mathrm{~cm}$ x $160 \mathrm{~cm}$ x $30 \mathrm{~cm}$. Jarak antar petak dalam satu blok adalah $30 \mathrm{~cm}$, dan jarak antar blok adalah $50 \mathrm{~cm}$. Petak kemudian ditutup dengan mulsa jerami dan siap ditanami. Lobang tanam dibuat dengan menggunakan tugal. Untuk selada, jarak lobang tanam adalah $20 \times 20 \mathrm{~cm}$ dan dalam setiap petak percobaan terdapat 40 lobang tanam dalam 4 barisan. Untuk kelor, lobang tanam dibuat dengan jarak 60 x $30 \mathrm{~cm}$, dan dalam setiap petak terdapat 21 lobang tanam dalam 3 barisan. Setiap lobang tanam ditambahkan pupuk kandang sapi masing-masing $80 \mathrm{~g}$ untuk selada dan $400 \mathrm{~g}$ untuk kelor. Petak-petak percobaan siap ditanami.

Bibit selada dipindah tanam ke lapangan setelah berumur 4 minggu dan bibit kelor setelah berumur 2 bulan di polibag. Penanaman dilakukan pada sore hari, dan setelah bibit ditanam dilakukan penyiraman dengan menggunakan gembor.

Ketiga pupuk organik yang digunakan disemprotkan dengan menggunakan dosis dan konsentrasi anjuran. Penyemprotan pupuk organik dilakukan dengan interval waktu 10 hari dimulai pada umur 14 hari setelah tanam. Pada tanaman kelor dilakukan penyemprotan sebanyak 4 kali, yaitu pada saat berumur 14, 24, 34 dan 44 hari setelah tanam, sementara pada tanaman selada dilakukan sebanyak 2 kali yaitu pada saat tanaman berumur 14 dan 24 hari setelah tanam. Petak kontrol tidak dilakukan penyemprotan dengan pupuk organik.

Pemeliharaan tanaman meliputi penyiraman, penyulaman, pengendalian hama, penyakit dan gulma. Penyiraman dilakukan tiga hari sekali hingga tanaman selada berumur 20 hari, dan setelah itu dilakukan seminggu sekali. Penyulaman dilakukan paling lambat saat tanaman berumur seminggu jika ditemukan tanaman yang mati atau pertumbuhannya terganggu dengan menggunakan tanaman cadangan. Gulma dan rerumputan yang tumbuh dikendalikan dengan mencabut langsung. Hama dan penyakit jika ditemukan, dikendalikan dengan menggunakan pestisida. 
Panen selada dilakukan saat tanaman berumur 35-40 hari setelah tanam dengan mencabut seluruh tanaman. Untuk kelor, panen dilakukan saat tanaman berumur 60 hari setelah tanam dengan memotong batang, cabang dan daun, dan menyisakan tanaman setinggi $100 \mathrm{~cm}$.

Sampel ditentukan sejumlah 8 tanaman untuk selada dan 6 tanaman untuk kelor. Masingmasing barisan tanaman diambil 2 tanaman sebagai sampel. Parameter yang diamati untuk kedua tanaman yang ditumpang sarikan adalah tinggi tanaman, jumlah daun, dan bobot segar panenan per tanaman dan per petak. Tinggi tanaman dan jumlah daun diamati setiap 10 hari sekali sejak tanaman berumur 2 minggu setelah tanam. Bobot segar panenan diamati saat akhir percobaan.

Data yang terkumpul dianalisis dengan menggunakan Analisis Keragaman pada taraf 5 persen, dan jika terdapat pengaruh maka dilanjutkan dengan menggunakan uji Beda Nyata Jujur pada tarat yang sama.

\section{HASIL DAN PEMBAHASAN}

Aplikasi pupuk organik pada tumpang sari tanaman kelor-selada di lahan kering memberikan pengaruh yang nyata terhadap tinggi tanaman dan jumlah daun setiap waktu pengamatan pada kedua tanaman, kecuali pada waktu pengamatan umur 14 hari setelah tanam. Sementara terhadap bobot segar panenan per tanaman dan bobot segar panenan per petak memberikan pengaruh yang nyata pada kedua tanaman yang ditumpangsarikan. Rekapitulasi hasil analisis keragaman terhadap parameter yang diamati terhadap tanaman kelor dan tanaman selada disajikan pada Tabel 1 dan Tabel 2.

Tabel 1. Rekapitulasi hasil analisis keragaman tinggi tanaman, jumlah daun pada setiap waktu pengamatan, bobor segar panenan per tanaman dan bobot segar panenan per petak tanaman kelor

\begin{tabular}{cl}
\hline Parameter & Hasil Analisis \\
\hline Tinggi tanaman & tn \\
Umur 14 hari setelah tanam & $\mathrm{s}$ \\
Umur 24 hari setelah tanam & $\mathrm{s}$ \\
Umur 34 hari setelah tanam & $\mathrm{s}$ \\
Umur 44 hari setelah tanam & $\mathrm{s}$ \\
Umur 54 hari setelah tanam & \\
Jumlah daun & tn \\
Umur 14 hari setelah tanam & $\mathrm{s}$ \\
Umur 24 hari setelah tanam & $\mathrm{s}$ \\
Umur 34 hari setelah tanam & $\mathrm{s}$ \\
Umur 44 hari setelah tanam & $\mathrm{s}$ \\
Umur 54 hari setelah tanam & $\mathrm{s}$ \\
Bobot segar panenan per tanaman & $\mathrm{s}$ \\
Bobot segar panenan per petak & $\mathrm{s}$
\end{tabular}

Keterangan: $\operatorname{tn}=$ berbeda tidak nyata, $\mathrm{s}=$ berbeda nyata pada taraf nyata $5 \%$ 
Hasil uji lanjut terhadap tinggi tanaman dan jumlah daun tanaman yang menunjukkan beda nyata disajikan pada Tabel 3 dan Tabel 4. Sedangkan hasil uji lanjut terhadap tinggi tanaman dan jumlah daun tanaman selada yang menunjukkan beda nyata disajikan pada Tabel 5 .

Tabel 2. Rekapitulasi hasil analisis keragaman terhadap tinggi tanaman, jumlah daun pada setiap waktu pengamatan, bobor segar panenan per tanaman dan bobot segar panenan per petak tanaman selada

\begin{tabular}{ll}
\hline Parameter & Hasil Analisis \\
\hline Tinggi tanaman & tn \\
Umur 14 hari setelah tanam & $\mathrm{s}$ \\
Umur 24 hari setelah tanam & $\mathrm{s}$ \\
Umur 34 hari setelah tanam & \\
Jumlah daun & tn \\
Umur 14 hari setelah tanam & tn \\
Umur 24 hari setelah tanam & $\mathrm{s}$ \\
Umur 34 hari setelah tanam & $\mathrm{s}$ \\
Bobot segar panenan per tanaman & $\mathrm{s}$ \\
Bobot segar panenan per petak &
\end{tabular}

Keterangan :

ns $\quad=$ non significant (tidak berbeda nyata) pada taraf nyata $5 \%$

$\mathrm{s} \quad=$ significant (berbeda nyata) pada taraf nyata $5 \%$

Tabel 3. Hasil uji lanjut pada setiap rata-rata tinggi tanaman kelor $(\mathrm{cm})$ yang menunjukkan beda nyata pada analisis keragaman

\begin{tabular}{llllll}
\hline \multirow{2}{*}{ Perlakuan } & \multicolumn{6}{c}{ Umur (hari setelah tanam) } & & \\
\cline { 2 - 6 } & $\mathbf{1 4}$ & $\mathbf{2 4}$ & $\mathbf{3 4}$ & $\mathbf{4 4}$ & $\mathbf{5 4}$ \\
\hline Tanpa Pupuk & 15.2 & $22.21 \mathrm{a}$ & $34.98 \mathrm{a}$ & $45.68 \mathrm{a}$ & $66.48 \mathrm{a}$ \\
Organik & 13.9 & $31.06 \mathrm{~b}$ & $42.99 \mathrm{~b}$ & $58.84 \mathrm{~b}$ & $77.76 \mathrm{~b}$ \\
BIOTA Plus & 14.3 & $33.91 \mathrm{~b}$ & $47.20 \mathrm{bc}$ & $68.29 \mathrm{bc}$ & $84.76 \mathrm{~b}$ \\
Bio EXTRIM & 14.9 & $38.43 \mathrm{~b}$ & $51.46 \mathrm{c}$ & $75.70 \mathrm{c}$ & $97.38 \mathrm{c}$ \\
ORGANOX & 14.5 & $21.40 \mathrm{a}$ & $32.60 \mathrm{a}$ & $43.32 \mathrm{a}$ & $60.30 \mathrm{a}$ \\
Monokultur Kelor & - & 8.32 & 7.99 & 10.39 & 10.86 \\
\hline \multicolumn{1}{c}{ BNJ } & &
\end{tabular}

Keterangan : Nilai rata-rata yang diikuti oleh huruf yang berbeda pada kolom yang sama menunjukkan berbeda nyata berdasarkan uji BNJ pada taraf 5\%

Tinggi tanaman dan jumlah daun tanaman kelor dan tanaman selada pada saat umur 14 hari setelah tanam tidak terdapat perbedaan yang nyata antar perlakuan disebabkan karena pupuk organik baru aplikasikan pada umur 2 minggu setelah tanam, sehingga aplikasi pupuk organik belum menunjukkan pengaruh. Pengaruh aplikasi pupuk organik terhadap tinggi tanaman dan jumlah daun baik pada tanaman kelor maupun selada sudah mulai tampak pada pengamatan tinggi tanaman umur 24, 34, 44 dan 54 hari setelah tanam. 
Tampak pada Tabel 3 dan Tabel 4, bahwa pengaruh aplikasi ketiga jenis pupuk organik terhadap tinggi tanaman dan jumlah daun tanaman kelor menunjukkan perbedaan yang nyata dibandingkan dengan tanpa pupuk organik dan monokultur tanaman kelor, yang berarti ketiga jenis pupuk organik (Biota Plus, Bio Extrim dan Organox) yang diaplikasikan mampu mendukung pertumbuhan tinggi tanaman dan jumlah daun. Hal ini disebabkan karena ketiga pupuk organik tersebut mengandung unsur hara yang lengkap makro dan mikro sehingga dapat menyediakan unsur hara yang dibutuhkan serta dapat memacu proses pertumbuhan vegetatif tanaman. Pemberian pupuk organik cair yang mengandung unsur hara makro dan mikro akan menyebabkan terpacunya pembelahan sel dan pembentukan sel-sel baru untuk pembentukan organ tanaman.

Tabel 4. Hasil uji lanjut pada setiap rata-rata jumlah daun kelor yang menunjukkan beda nyata pada analisis keragaman

\begin{tabular}{llllll}
\hline \multicolumn{1}{c}{ Perlakuan } & \multicolumn{6}{c}{ Umur (hari setelah tanam) } & & \\
& $\mathbf{1 4}$ & $\mathbf{2 4}$ & $\mathbf{3 4}$ & $\mathbf{4 4}$ & $\mathbf{5 4}$ \\
\hline Tanpa Pupuk Organik & 8.76 & $12.50 \mathrm{a}$ & $13.63 \mathrm{a}$ & $15.08 \mathrm{a}$ & $16.53 \mathrm{a}$ \\
BIOTA Plus & 9.13 & $15.37 \mathrm{~b}$ & $16.28 \mathrm{~b}$ & $18.00 \mathrm{~b}$ & $18.63 \mathrm{~b}$ \\
Bio EXTRIM & 8.75 & $16.08 \mathrm{~b}$ & $17.12 \mathrm{~b}$ & $18.31 \mathrm{~b}$ & $19.88 \mathrm{~b}$ \\
ORGANOX & 9.08 & $16.98 \mathrm{~b}$ & $18.59 \mathrm{~b}$ & $20.56 \mathrm{c}$ & $22.31 \mathrm{c}$ \\
Monokultur Kelor & 8.75 & $12.00 \mathrm{a}$ & $13.46 \mathrm{a}$ & $14.75 \mathrm{a}$ & $16.25 \mathrm{a}$ \\
\hline \multicolumn{1}{c}{ BNJ } & - & 2.95 & 3.28 & 2.36 & 2.27 \\
\hline
\end{tabular}

Keterangan : Nilai rata-rata yang diikuti oleh huruf yang berbeda pada kolom yang sama menunjukkan berbeda nyata berdasarkan uji BNJ pada taraf 5\%

Pengaruh jenis pupuk organik yang diaplikasikan terhadap tinggi tanaman dan jumlah daun tanaman kelor (Tabel 3 dan Tabel 4) menunjukkan bahwa pupuk Organox memberikan pengaruh yang lebih baik terhadap tinggi tanaman dan jumlah daun dibandingkan dengan Bio Extrim dan Biota Plus. Hal ini diduga disebabkan selain kandungan unsur hara yang lengkap makro dan mikro. pupuk organik Organox juga mengandung mikrobia yang menguntungkan dalam membantu penyediaan unsur hara. seperti Azospirillum sp.. Azotobacter sp.. Rhizobium sp.. Pseudomonas sp.. Bacillus sp. yang mampu menambat N (nitrogen) dari udara dan meningkatkan kelarutan fosfat $(\mathrm{P})$. K serta unsur hara lainnya di dalam tanah sehingga unsur hara lebih tersedia bagi tanaman untuk proses pertumbuhan tinggi tanaman dan jumlah daun. Selain itu pupuk organik tersebut juga mengandung fitohormon seperti auxin yang dapat menginduksi dan memacu pertumbuhan batang dan daun tanaman. James and Olivares (1997) menyatakan bahwa bakteri fiksasi $\mathrm{N}_{2}$ yang hidup bebas pada daerah perakaran dan jaringan tanaman. seperti Pseudomonas spp.. Bacillus. Azotobacter. Azospirillum. dan Herbaspirillum telah terbukti mampu melakukan fiksasi $\mathrm{N}_{2}$. Azotobacter sp. merupakan bakteri non simbiotik yang mampu menambat $\mathrm{N}$ dari udara. Selain mampu menambat nitrogen. bakteri ini juga mengeluarkan hormon yang sama dengan hormon pertumbuhan tanaman. seperti giberelin. IAA. kinetin. dan vitamin B. Vitamin B ini berfungsi untuk aktivitas bakteri dalam peningkatan kemampuan memfiksasi $\mathrm{N}$ dari atmosfer. Azotobacter sp. dapat meningkatkan pertumbuhan 
melalui pasokan nitrogen. pasokan pengatur tumbuh. dan membuat kondisi tanah lebih menguntungkan untuk pertumbuhan tanaman (Alexander. 1977). Pseudomonas sp. dan Bacillus sp. adalah jenis bakteri yang mampu meningkatkan kelarutan $\mathrm{P}$ dalam tanah dan memiliki peran yang dapat memperbaiki pertumbuhan akar serta meningkatkan serapan hara sehingga dapat meningkatkan efisiensi pemupukan (Glick. 1995; Rao. 1994; Widawati. 2005).

Hasil uji lanjut parameter tinggi tanaman dan jumlah daun tanaman selada pada setiap waktu pengamatan (Tabel 5). menunjukkan pola pengaruh aplikasi jenis pupuk organik yang sama seperti pada tanaman kelor. Pupuk organik Bio Extrim dan Organox menunjukkan pengaruh yang berbeda nyata dibandingkan dengan tanpa pupuk organik (kontrol) dan monokultur. Sedangkan pupuk organik Biota Plus tidak berbeda nyata dibanding tanpa pupuk oganik. Aplikasi pupuk organik Organox memberikan pengaruh yang lebih baik terhadap tinggi tanaman dan jumlah daun tanaman dibandingkan dengan Biota Plus dan Bio Extrim.

Tabel 5. Hasil uji lanjut pada setiap rata-rata tinggi tanaman dan jumlah daun tanaman selada yang menunjukkan beda nyata pada analisis keragaman

\begin{tabular}{lllllll}
\hline \multirow{2}{*}{ Perlakuan } & \multicolumn{3}{c}{ Umur (hari setelah tanam) } & \multicolumn{3}{c}{ Umur (hari setelah tanam) } \\
\cline { 2 - 7 } & $\mathbf{1 4}$ & $\mathbf{2 4}$ & $\mathbf{3 4}$ & $\mathbf{1 4}$ & $\mathbf{2 4}$ & $\mathbf{3 4}$ \\
\hline Tanpa Pupuk & 8.47 & $14.33 \mathrm{ab}$ & $18.38 \mathrm{ab}$ & 5.69 & $9.50 \mathrm{a}$ & $13.88 \mathrm{a}$ \\
Organik & 8.22 & $16.44 \mathrm{bc}$ & $20.62 \mathrm{bc}$ & 5.88 & $12.38 \mathrm{~b}$ & $17.19 \mathrm{~b}$ \\
BIOTA Plus & 8.59 & $17.01 \mathrm{c}$ & $21.10 \mathrm{c}$ & 6.06 & $13.50 \mathrm{~b}$ & $18.06 \mathrm{bc}$ \\
Bio EXTRIM & 7.97 & $17.91 \mathrm{c}$ & $24.16 \mathrm{~d}$ & 5.63 & $14.69 \mathrm{~b}$ & $19.00 \mathrm{c}$ \\
ORGANOX & 8.63 & $13.84 \mathrm{a}$ & $17.78 \mathrm{a}$ & 5.78 & $9.345 \mathrm{a}$ & $13.125 \mathrm{a}$ \\
Monokultur Selada & - & 2.63 & 2.79 & - & 2.74 & 1.30 \\
\hline BNJ & - &
\end{tabular}

Keterangan : Nilai rata-rata yang diikuti oleh huruf yang berbeda pada kolom yang sama menunjukkan berbeda nyata berdasarkan uji BNJ pada taraf $5 \%$

Hasil uji lanjut parameter bobot segar panenan per tanaman dan bobot segar panenan per petak pada tanaman kelor dan tanaman selada (Tabel 5). menunjukkan bahwa pengaruh aplikasi ketiga jenis pupuk organik terhadap bobot segar panenan per tanaman dan bobot segar panenan per petak pada tanaman kelor dan tanaman selada bebeda nyata dibandingkan dengan tanpa pupuk organik baik pada tanaman kelor maupun tanaman selada. yang berarti ketiga jenis pupuk organik (Biota Plus. Bio Extrim dan Organox) yang diaplikasikan mampu mendukung peningkatan bobot segar panenan per tanaman dan bobot segar panenan per petak pada tanaman kelor dan tanaman selada. Pupuk organik Organox memberikan pengaruh yang lebih baik dibandingkan dengan Bio Extrim dan Biota Plus. Hal ini sejalan dengan pertumbuhan tinggi tanaman dan jumlah daun pada kedua tanaman. dimana tanaman yang lebih tinggi dan jumlah daun yang lebih banyak akan menghasilkan bobot segar panenan per tanaman dan bobot segar per petak pada kedua tanaman.

Bobot segar per petak tertinggi diperoleh pada penanaman monokultur. berbeda nyata dibandingkan perlakuan pupuk organik dan tanpa pupuk organik. kecuali dengan perlakuan pupuk organik Organox. Perbedaan hasil per petak pada penanaman monokultur dengan perlakuan pupuk organik dan tanpa pupuk organik disebabkan karena jumlah jumlah populasi 
tanaman yang berbeda antara tanaman monokultur dengan penanaman secara tumpang sari untuk masing-masing tanaman. Populasi tanaman kelor pada sistem tanam tumpangsari sebesar $60 \%$ dari populasi tanaman kelor monokultur. sedangkan populasi tanaman selada pada sistem tanam tumpangsari sebesar $57 \%$ dari tanaman populasi tanaman selada monokultur. Namun demikian perlakuan pupuk organik Organox memberikan pengaruh yang tidak berbeda nyata dibandingkan penanaman monokultur pada kedua tanaman. Hal ini diduga disebabkan pola kombinasi tanaman yang ditumpangsarikan dan perlakuan aplikasi pupuk organik saling menguntungkan untuk kedua tanaman. Tanaman selada merupakan tanaman semusim yang pertumbuhan vegetatifnya cepat. sehingga tanaman selada yang ditanam secara tumpangsari mampu berkompetisi dengan tanaman utama. yaitu kelor. Tanaman sela yang lebih rendah dari tanaman pokok juga berguna sebagai penutup tanah. sehingga kelembaban tanah dapat dipertahankan. Tanaman pokok yang lebih tinggi memberikan pengaruh naungan bagi tanaman sela. Naungan dan tajuk dari tanaman utama dapat bermanfaat bagi tanaman sela. Nurmas (2011) menjelaskan bahwa keberhasilan tumpangsari sangat ditentukan oleh kombinasi jenisjenis tanaman penyusun. Kombinasi dua jenis tanaman berumur tidak sama. kebutuhan cahaya matahari. CO2. air. dan unsur hara maksimum masing-masing jenis tanaman terjadi pada waktu berbeda bila kedua jenis tanaman tersebut ditanam pada waktu bersamaan. Selanjutnya. Palaniappan (1985) menyatakan bahwa pada pola tanam tumpangsari. hasil masing-masing jenis tanaman dapat mengalami penurunan dibandingkan dengan jika ditanam tunggal. namun karena diimbangi oleh adanya hasil tanaman yang lainnya sehingga keseluruhan hasil tanaman lebih tinggi dibandingkan hasil tunggal.

Tabel 6. Rata-rata bobot segar per tanaman. bobot segar per petak tanaman kelor dan selada

\begin{tabular}{|c|c|c|c|c|c|}
\hline \multirow{3}{*}{ Perlakuan } & \multicolumn{4}{|c|}{ Bobot segar (g) } & \multirow{3}{*}{ NKL } \\
\hline & \multicolumn{2}{|c|}{ Panenan kelor } & \multicolumn{2}{|c|}{ Panenan selada } & \\
\hline & $\begin{array}{l}\text { Per } \\
\text { tanaman }\end{array}$ & $\begin{array}{l}\text { Per } \\
\text { petak }\end{array}$ & $\begin{array}{l}\text { Per } \\
\text { tanaman }\end{array}$ & $\begin{array}{l}\text { Per } \\
\text { petak }\end{array}$ & \\
\hline Tanpa Pupuk Organik & $341.41 \mathrm{a}$ & $7.009 .67 \mathrm{a}$ & $81.61 \mathrm{a}$ & $2.897 .75 \mathrm{a}$ & $0.93 \mathrm{a}$ \\
\hline BIOTA Plus & $486.30 \mathrm{~b}$ & $10.085 .07 \mathrm{~b}$ & $127.13 b$ & $4.710 .15 b$ & $1.41 b$ \\
\hline Bio EXTRIM & $545.79 b c$ & $11.166 .18 b$ & $141.24 b$ & $5.599 .53 \mathrm{c}$ & $1.62 \mathrm{c}$ \\
\hline ORGANOX & $635.44 c$ & $12.861 .93 \mathrm{bc}$ & $157.42 b$ & $6.364 .96 \mathrm{~d}$ & $1.86 \mathrm{~d}$ \\
\hline Monokultur & $313.00 \mathrm{a}$ & $14.362 .24 \mathrm{c}$ & $79.53 a$ & $6.621 .05 \mathrm{~d}$ & \\
\hline BNJ & 100.83 & 3.062 .67 & 44.25 & 745.90 & 0.17 \\
\hline
\end{tabular}

Keterangan : Nilai rata-rata yang diikuti oleh huruf yang berbeda pada kolom yang sama menunjukkan berbeda nyata berdasarkan uji BNJ pada taraf $5 \%$

Untuk mengetahui peningkatan produktivitas lahan dari sistem tumpangsari kelor-selada dibandingkan dengan penanaman monokultur pada masing-masing tanaman dapat dilihat dari nilai kesetaraan lahan (NKL). Berdasarkan nilai kesetaraan lahan (Tabel 6). menunjukkan bahwa sistem tumpangsari kelor-selada mampu meningkatkan produktivitas lahan.

Nilai NKL berdasarkan bobot segar tertinggi terdapat pada perlakuan aplikasi pupuk organik Organox. yaitu sebesar 1.86. Nilai NKL 1.86 menunjukkan bahwa diperlukan lahan 
seluas 1.86 kali lebih besar untuk penanaman monokultur kelor dan selada agar hasil yang setara dengan hasil tumpangsari tersebut. Perlakuan aplikasi Organox dapat meningkatkan nilai NKL sebesar 86\% dibandingkan NKL tanaman Kelor dan Selada secara monokultur.

\section{KESIMPULAN DAN SARAN}

Aplikasi pupuk organik pada tumpangsari kelor-selada meningkatkan pertumbuhan dan hasil tanaman kelor dan selada. kecuali terhadap tinggi tanaman dan jumlah daun umur 14 hari setelah tanam. Aplikasi pupuk organik Organox memberikan pengaruh terbaik dibandingkan dengan Bio Extrim dan Biota Plus terhadap tinggi tanaman. jumlah daun. bobot segar panenan per tanaman. dan bobot segar panenan per petak baik pada tanaman kelor maupun pada tanaman selada. Aplikasi pupuk organik cair (Organox. Bio Extrim dan Biota Plus) juga mampu meningkatkan produktivitas lahan. Nilai kesetaraan lahan (NKL) tertinggi ditunjukkan oleh perlakuan pupuk Organox (1.86). diikuti oleh Bio Extrim (1.62) dan Biota Plus (1.41). serta terendah terdapat pada perlakuan tanpa pupuk organik (0.93). Penggunaan pupuk organik Organox. Bio Extrim dan Biota Plus dapat dijadikan bahan pertimbangan dalam meningkatkan hasil tanaman kelor-selada yang ditanam secara tumpang sari di lahan kering.

\section{Ucapan Terima Kasih}

Penelitian ini dilaksanakan menggunakan Sumber Dana DIPA BLU (PNBP) Universitas Mataram dengan surat perjanjian pelaksanaan penelitian No.: 1379.I/ UN18.L1/PP/2018 tanggal 02 Mei 2018.

\section{DAFTAR PUSTAKA}

Agustina. L. dan I. Semaoen. 1995. Pengembangan Lahan Kering yang Berkelanjutan di Kawasan Timur Indonesia dan Tehnologi yang Relevan . Kasus NTB. Hal 73-86. Dalam Damar Jaya. Abdullah dan Ma'shum (eds) Prosiding Lokakarya Lahan Kering. Fakultas Pertanian Unram. Mataram.

Alexander. M. 1977. Introduction to soil mycrobiology. 2nd Ed. John Wiley and Sons. New York. 467 p.

BPS. 2002. Statistik Indonesia Tahun 2002. Biro Pusat Statistik.

da Silva. JPV; Marcelo Gossmann; Tatiana M. Serra; Simoni M.P. Meneghetti. 2010. Moringa

oleifera oil: Studies of characterization and biodiesel production. Biomass and Bioenergy 34(10):1527-1530.

Departemen Pertanian. 2017. http://database.deptan.go.id/bdspweb/f4freeframe. Asp. Diakses [19 Desember 2017].

Edward. E.; Shabani A. O. Chamshama; Yonika M. Ngaga; dan Mathew A. Mndolwa. 2014.

Survival. growth and biomass production of Moringa oleifera provenances at Gairo inland plateau and Ruvu Coastal Region in Tanzania. African Journal of Plant Science Vol. 8(1). pp. 54 - 64. DOI: 10.5897/AJPS12.158

Glick. B. R. 1995. The enhancement of plant growth by free living bacteria. Canadian Journal Microbiology. 4: 109-117. 
James. E. and F.L. Olivares. 1997. Infection and colonization of sugarcane and other graminaceous plants by endophytic diazotrophicus. Plant Science. 17:77-119.

Lingga. P. 2006. Petunjuk penggunaan pupuk . Penebar Swadaya Jakarta. $160 \mathrm{hlm}$.

Nurmas. A. 2011. Kajian Waktu Tanam dan Kerapatan Tanaman Jagung Sistem Tumpangsari dengan Kacang Tanah terhadap Nilai LER dan Indeks Kompetisi. Jurnal Agriplus. 21(1): 61-67.

Palaniappan. 1985. Cropping System in the Tropics. Principle and Management. Wiley Easterm Limited. New Dehli.

Pusat Penelitian dan Pengembangan Tanah dan Agroklimat. 2002. Arahan Pewilayahan Komoditas Pertanian Unggulan Nasional. Pusat Penelitian dan Pengembangan Tanah dan Agroklimat. Bogor. $43 \mathrm{hlm}$.

Rao. N. S. S. 1994. Mikroorganisme tanah dan pertumbuhan tanaman. Ter jemahan: Susilo. H. Edisi ke-2. Jakarta: Penerbit Universitas Indonesia.

Rashid. U.. Anwar. F.. Moser. B.R.. Knothe. G. 2008. Moringa oleifera oil: A possible source of biodiesel. Bioresource Technol. 99:8175-8179

Rini dan Sumarni. N.. 2005. Budidaya Tanaman Sayuran dengan Sistem Hidroponik. Balai Penelitian Tanaman Sayuran. Bandung.

Widawati. 2005. Daya Pacu Aktivator Fungi Asal Kebun Biologi Wamena terhadap Kematangan dan Hara Kompos. serta Kandungan Mikroba Pelarut Fosfat dan Penambat Nitrogen. J. Biodiversity 6(4): 238-241.

Zulkarnain. 2005. Pertumbuhan dan Hasil Selada pada Berbagai Kerapatan Jagung Dalam Pola Tumpang sari. Journal Stigma. Univ. Andalas. Vol. XIII. No. 3 : 345-348 